\title{
Dexmedetomidine and fentanyl exhibit temperature dependent effects on human respiratory cilia
}

\author{
Nils Welchering ${ }^{1}$, Sebastian Ochoa ${ }^{1}$, Xin Tian $^{2}$, Richard Francis ${ }^{3}$, Maliha Zahid $^{3}$, Ricardo Muñoz $^{4}$ and \\ Cecilia W. Lo $^{3 *}$
}

1 Department of Pediatrics, University of Pittsburgh, Pittsburgh, PA, USA

${ }^{2}$ Office of Biostatistics Research, NHLBI, Washington, DC, USA

${ }^{3}$ Department of Developmental Biology, University of Pittsburgh, Pittsburgh, PA, USA

${ }^{4}$ Department of Critical Care Medicine, University of Pittsburgh, Pittsburgh, PA, USA

\section{Edited by:}

Demet Demirkol, Koç University

School of Medicine, Turkey

\section{Reviewed by:}

Kathleen Ann Webster, Advocate Children's Hospital, USA

Richard Emil Lehman, Santa Barbara

Cottage Children's Hospital, USA

Tanil Kendirli, Ankara University

School of Medicine, Turkey

*Correspondence:

Cecilia W. Lo, Department of

Developmental Biology, University of

Pittsburgh, 530 45th Street, 8120

Rangos Research Center, Pittsburgh,

PA 15201, USA

e-mail: ce/36@pitt.edu
Background: Dexmedetomidine (dex) is commonly used in intensive care due to its effective sedation and analgesia with few adverse effects and minimal respiratory depression. However, we recently observed that exposing mouse epithelial respiratory cells to dex decreased ciliary beat frequency (CBF), suggesting dex may pose pulmonary risk.

Objective:The purpose of this study is to determine the effects of dex at clinically relevant doses on CBF in human respiratory epithelia.

Methods: Human nasal epithelial cilia were obtained from the inferior nasal turbinate with a rhinoprobe and placed in culture medium at $15^{\circ} \mathrm{C}$ and $37^{\circ} \mathrm{C}$. At 5 and $30 \mathrm{~min}$, video-microscopy was used to assess $\mathrm{CBF}$, either without (control) or with different concentrations $(1,5$, and $10 \mathrm{nM})$ of dex, fentanyl (fen), and dex + fen combination.

Results: At $15^{\circ} \mathrm{C}, \mathrm{CBF}$ was lower in the dex group compared to controls at 5 and $30 \mathrm{~min}$. At $37^{\circ} \mathrm{C}$, there was a significant increase in CBF with dex at 5 and 30 min, except for dex at $5 \mathrm{nM}$ after $5 \mathrm{~min}$, which showed a significant decrease. At $15^{\circ} \mathrm{C}$ the combination of dex + fen showed a positive interaction, causing less ciliary inhibition as expected. In contrast, no interaction between drugs was seen between dex and fen at $37^{\circ} \mathrm{C}$.

Conclusion: At low temperatures, dex reduces CBF in human respiratory epithelia, whereas dex increases CBF at physiologic temperature in vitro. Whether these effects translate into clinical consequences during hypothermia, as with cardiopulmonary bypass surgery will require further studies.

Keywords: dexmedetomidine, ciliary beat frequency, hypothermia, human cilia, fentanyl, airway cilia motility

\section{INTRODUCTION}

In intensive care medicine, physicians face the challenge of providing effective sedation while minimizing adverse effects. Sedatives are necessary to provide patient comfort and safety, but their administration must be weighed against deleterious consequences. Dexmedetomidine (dex), an alpha-2 agonist, is being increasingly used due to its effective sedative property (1). This has made dex appealing in cardiac intensive care, where hemodynamic instability warrants medications that minimally compromise cardiovascular and respiratory function, especially during postsurgical care after cardiopulmonary bypass surgery (CBP) $(2,3)$. However, we recently obtained data from in vitro studies of the mouse respiratory epithelia showing dex decreased ciliary beat frequency $(\mathrm{CBF})$, an objective measure of ciliary motility, thereby raising concerns about dex compromising lung clearance function. CBF plays an essential role in propelling mucus and foreign particles out of the airways. Although studies have identified a multitude of factors that can depress CBF, including anesthetics and hypothermia, the effects of dex on human respiratory epithelia have not been specifically examined (4-6). Therefore, we undertook the present study to determine the effects of dex on ciliary motility at $15^{\circ} \mathrm{C}$ and $37^{\circ} \mathrm{C}$ in humans.

\section{MATERIALS AND METHODS \\ OBTAINING HUMAN RESPIRATORY EPITHELIA}

This study was approved by the University of Pittsburgh Internal Review Board. Informed consent was obtained from all volunteers. Human nasal epithelial cells from 10 adult volunteers were collected with a rhinoprobe curette (Arlington Scientific, Springville, UT, USA) using a nasal speculum. The curette was gently scraped three times over the surface of each inferior nasal turbinate and the tissue was immediately placed in $5 \mathrm{ml}$ RPMI- 1640 culture medium (Leibowitz-15 medium) at room temperature. Tissue obtained from one person was used as a single sample.

\section{PROCESSING OF HUMAN RESPIRATORY EPITHELIA AND PREPARATION OF CELL GROUPS}

Samples from the same individual were placed in media precooled or heated at 15 or $37^{\circ} \mathrm{C}$, immediately after extracting the samples from healthy volunteers. Video-microscopy was performed 5 and 
30 min after placing the cells in the media, and CBF calculated from these videos. Media contained either no drug (control group), or an anesthetic drug at 1,5 , and $10 \mathrm{nM}$ concentration comprising: (a) dex, (b) fentanyl (fen), or (c) dex + fen combination. These concentrations are equivalent to therapeutic plasma concentrations achieved during the course of routine clinical care $(7,8)$. To ensure similar sampling from each subject for each condition, tissue from five different volunteers was obtained and tested across all conditions for a total of 1991 data points.

\section{MEASUREMENT OF CILIARY BEAT FREQUENCY}

Ciliary motion was recorded with a Leica DMIRE2 inverted microscope (Leica Microsystems, Buffalo Grove, IL, USA) using a 100× differential interference contrast (DIC) oil objective under DIC optics. To achieve a constant temperature of $15^{\circ} \mathrm{C}$, the microscope was placed in a room with an adjusted temperature of $15^{\circ} \mathrm{C}$. For $37^{\circ} \mathrm{C}$, the microscopy was conducted with a heated objective maintained at $37^{\circ} \mathrm{C}$ (Bioptechs, Butler, PA, USA). Videos were captured at 200 frames/s with a Phantom v4.2 high speed CMOS camera (Vision Research, Wayne, NJ, USA). To measure CBF, at least four videos were recorded for each condition. The videos obtained were analyzed with Image $(\mathrm{NIH})$ to create a kymograph for measuring the $\mathrm{CBF}$. The $\mathrm{CBF}$ was measured from eight regions of interest showing beating cilia per video and averaging five successive wavelengths per region using GIMP v2.6. Mean CBF was calculated for the control group as well as for dex, fen, dex + fen at both temperatures and time points.

\section{REAL TIME PCR ANALYSIS}

Nasal tissue was placed in culture on rat tail collagen-coated plates and media containing Ultroser G (Pall Corp.), and grown to confluence. Once confluence was achieved, collagen was removed using collagenase IV (Worthington Biochemicals, NJ, USA) and cells placed in suspension on a $37^{\circ} \mathrm{C}$ orbital shaker. The nasal epithelial cells lose their cilia as they grow on the collagen substratum, and when placed in suspension culture, they reciliate within 10-14 days (9). Once reciliation was confirmed, RNA from these cells was extracted using RNeasy Plus micro kit (Qiagen, cat \#74034), with generation of amplified cDNA (NuGen, Ovation RNA-Seq System, cat \#7102-32), and real time PCR (rt-PCR) performed using primers specific for human alpha and betaadrenergic receptors as well as opioid receptors. We also isolated nasal epithelial cells using a rhinoprobe to scrape the inferior turbinate under direct visualization using a nasal speculum. Cells were lysed using RNA lysis buffer (Qiagen), reverse transcription performed to generate CDNA and rt-PCR performed on this sample using the same primers as above for human alpha and beta-adrenergic as well as opiod receptors. All expression levels were normalized against human beta-actin gene.

\section{STATISTICAL ANALYSIS}

Differences in the mean CBF values between each drug category and control and difference between two temperatures for each drug or control were determined by heteroscedastic unpaired $t$ tests. A multivariate linear regression model was constructed to assess the main effect of the two drugs (dex and fen) and their interaction effect, separately, for each temperature. At each temperature, a regression model was fitted to the CBF data from the three drugs with control as the reference group. The intercept in the model is the estimated mean CBF for the control; the other positive or negative regression coefficients represent estimated increases or reductions in $\mathrm{CBF}$ for individual drugs and their interaction as compared to the control. The mean effect of the drug concentrations $(1,5$, or $10 \mathrm{nM})$ and time of exposure to drug (5 or $30 \mathrm{~min}$ ) were also examined using the regression model. All tests were twotailed and $p$-values $<0.05$ were considered significant. Analyses were performed with SAS 9.3 (SAS Institute, Cary, NC, USA).

\section{RESULTS}

In order to evaluate the effects of dex and fen on respiratory airway cilia, human nasal epithelial cells were obtained by curettage of the inferior nasal turbinate under direct visualization videomicroscopy performed. Cells from 10 volunteers ( 6 male, 4 female, median age 30) were obtained and a total of 1991 videos were obtained for this study (Table S1 in Supplementary Material).

\section{EFFECTS OF TEMPERATURE ON CILIARY BEAT FREQUENCY}

We examined temperature effects on $\mathrm{CBF}$ at $15^{\circ} \mathrm{C}$ to mimic conditions during $\mathrm{CPB}$ surgery and $37^{\circ} \mathrm{C}$ corresponding to body temperature. The $\mathrm{CBF}$ was obtained with exposure to temperature and drugs at 5 and $30 \mathrm{~min}$, with samples exposed to drugs including dex, fen, and dex + fen at 1,5 , and $10 \mathrm{nM}$ drug concentrations (Figure 1). Mean CBF was significantly lower in all

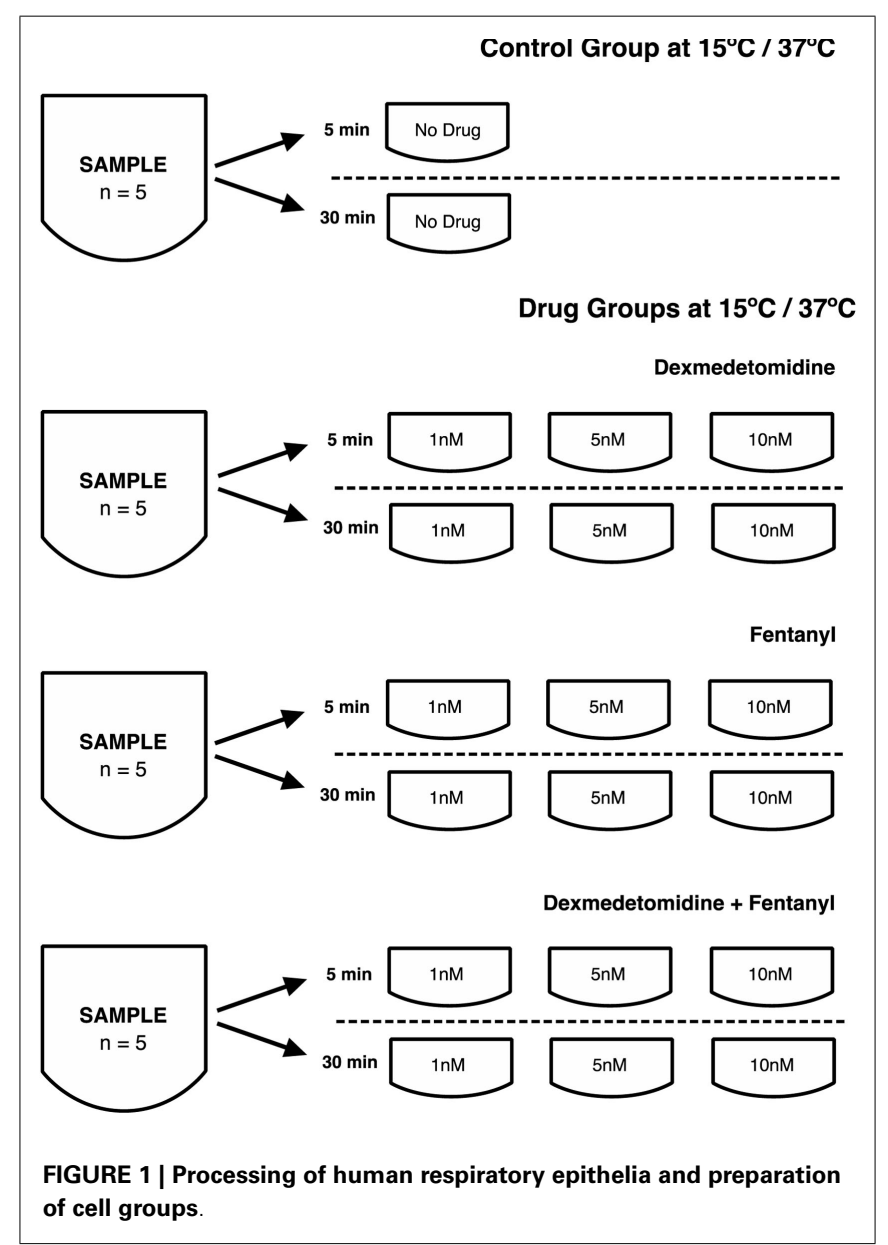


groups at 15 vs. $37^{\circ} \mathrm{C}$ at 5 and $30 \mathrm{~min}$ (Table S2 in Supplementary Material).

\section{EFFECTS OF DRUG EXPOSURE ON CILIARY BEAT FREQUENCY}

At $15^{\circ} \mathrm{C}$, exposure to drugs caused a reduction of CBF at all concentrations at 5 and $30 \mathrm{~min}$. Figure 2 shows mean CBF for each group $(p<0.05)$. When compared to controls, all drugs led to a significant increase in $\mathrm{CBF}$ at $37^{\circ} \mathrm{C}$, except for dex $5 \mathrm{nM}$ at $5 \mathrm{~min}$, which decreased CBF significantly (Figure 3). This unexpected cilia-depressant effect was no longer significant when the groups of dex with $5 \mathrm{nM}$ concentration at 5 and $30 \mathrm{~min}$ at $37^{\circ} \mathrm{C}$ were pooled together and compared to controls.

\section{DRUG-DRUG AND DRUG-TIME INTERACTION ON CILIARY BEAT FREQUENCY}

To investigate drug interactions between dex and fen, a multivariate linear regression model was constructed separately for each temperature. Although there are differences in CBF values under different concentrations or drug exposure times for each given drug, the average effect of drug concentration across the three drugs was not significant in the regression models. The average effect of drug exposure time was significant in the model at $37^{\circ} \mathrm{C}$, but not at $15^{\circ} \mathrm{C}$. When using controls as reference, the combination of dex + fen showed a positive interaction at $15^{\circ} \mathrm{C}$, causing less cilia inhibition than expected by summation of their individual effects. In contrast, no interaction was seen between dex and fen at $37^{\circ} \mathrm{C}$. Thus the estimated effect for $\mathrm{dex}+$ fen group was similar to the sum of the individual positive effects from dex and fen (Table 1).

Multivariate linear regression model was also used to show time effects on the CBF, as the analysis of variance did not show effects between different concentrations in each group. Accordingly, we pooled the data from different concentrations together to generate larger sample sizes. The regression model showed no significance for the effect of time at $15^{\circ} \mathrm{C}(p=0.663)$. In contrast, the time effect in the regression model was significant at $37^{\circ} \mathrm{C}$ $(p<0.05$, Table 2$)$. The individual means for each group showed a trend toward increased CBF at $30 \mathrm{~min}$ compared to $5 \mathrm{~min}$ for dex $(p=0.089)$ and $\operatorname{dex}+$ fen $(p=0.035)$.

\section{ADRENERGIC AND OPIOID RECEPTOR TRANSCRIPT EXPRESSION IN THE MOUSE AIRWAY EPITHELIA}

To examine possible molecular mechanism for the drug-drug interactions as well as drug-temperature and time effects of dex

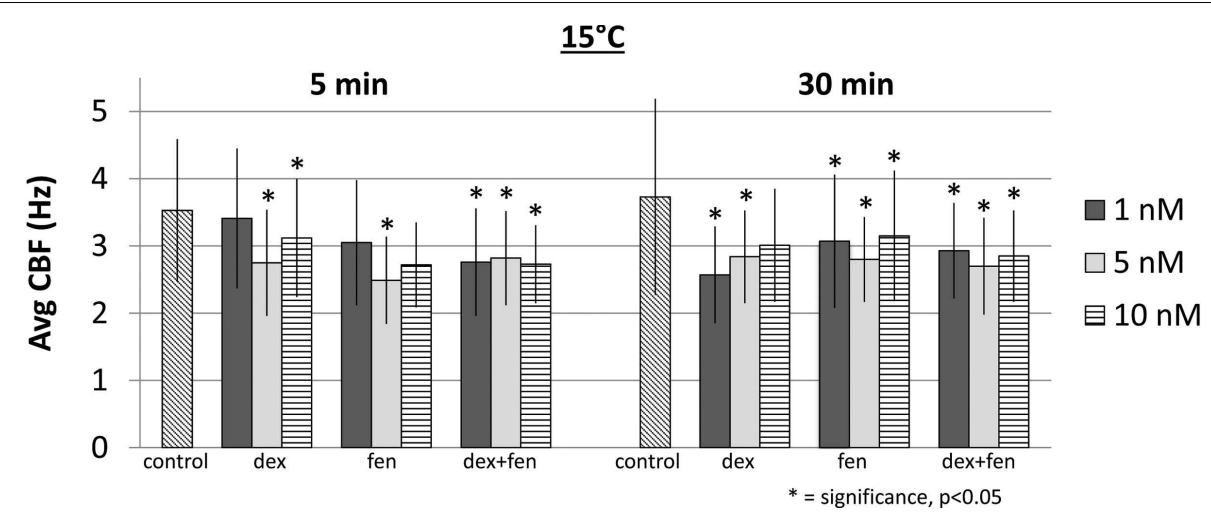

FIGURE 2 | Effects of drug exposure on ciliary beat frequency at $15^{\circ} \mathrm{C}$

\section{$\underline{37^{\circ} \mathrm{C}}$}

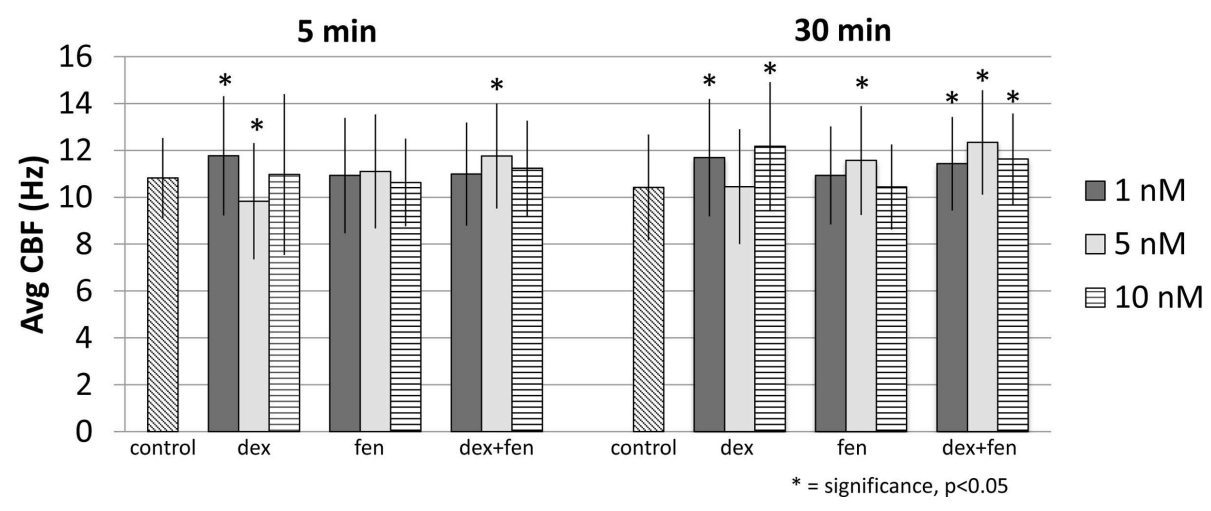

FIGURE 3 | Effects of drug exposure on ciliary beat frequency at $37^{\circ} \mathrm{C}$ 


\begin{tabular}{|c|c|c|c|c|}
\hline \multirow[t]{2}{*}{ Variables } & \multicolumn{2}{|c|}{$15^{\circ} \mathrm{C}(n=818)$} & \multicolumn{2}{|c|}{$37^{\circ} \mathrm{C}(n=1173)$} \\
\hline & Estimate (SE) & $p$-value & Estimate (SE) & $p$-value \\
\hline Intercept & $3.64(0.11)$ & $<0.0001$ & $10.51(0.30)$ & $<0.0001$ \\
\hline Fen & $-0.76(0.13)$ & $<0.0001$ & $0.28(0.32)$ & 0.37 \\
\hline Dex & $-0.67(0.13)$ & $<0.0001$ & $0.43(0.33)$ & 0.19 \\
\hline $\begin{array}{l}\text { Dex and fen } \\
\text { interaction }\end{array}$ & $0.60(0.15)$ & $<0.0001$ & $0.20(0.37)$ & 0.59 \\
\hline $\begin{array}{l}\text { Drug exposure } \\
\text { time ( } 30 \mathrm{vs} .5 \mathrm{~min} \text { ) }\end{array}$ & - & - & $0.31(0.14)$ & 0.023 \\
\hline
\end{tabular}

Table 2 | Multivariate regression model at $37^{\circ} \mathrm{C}$.

\begin{tabular}{lcccc}
\hline $\begin{array}{l}\text { Mean CBF in } \\
\text { Hz } \pm \text { SD }\end{array}$ & Control & Dex & Fen & Dex +fen \\
\hline At 5 min & $10.82 \pm 1.71$ & $10.82 \pm 2.93$ & $10.88 \pm 2.25$ & $11.35 \pm 2.16$ \\
At 30 min & $10.42 \pm 2.26$ & $11.39 \pm 2.65$ & $11.00 \pm 2.13$ & $11.81 \pm 2.09$ \\
$p$-value & 0.45 & 0.089 & 0.58 & 0.035 \\
\hline
\end{tabular}

and fen, we investigated expression of adrenergic and opioid receptor subtypes in reciliated human nasal epithelia with rt-PCR. Quantitative PCR showed high level of adrenergic beta-2 receptor expression followed by beta-1 receptors, without detectable expression of alpha-adrenergic or opioid receptors (Figure S1 in Supplementary Material). Quantitative PCR results carried out on freshly isolated nasal epithelial cells showed high levels of beta-adrenergic receptor expression (beta-1 > beta-2), without detectable alpha-adrenergic or opioid receptors, similar to our findings from the quantitative PCR carried out on the reciliating tissue.

\section{DISCUSSION}

In the intensive care setting, administration of anesthetic agents requires a thorough understanding of their pharmacodynamics and adverse effects. Dex, an alpha-2 agonist, has been extensively used for sedation and analgesia due to its favorable safety profile $(10,11)$. In a recent animal study, we found significant cilia-inhibitory effect with dex at $10 \mathrm{nM}$ at $22-24$ and $37^{\circ} \mathrm{C}$, but no significant effect at $15^{\circ} \mathrm{C}(12)$. The cilia-inhibitory effect of dex was reversed by combining dex with fen, which by itself was cilia-stimulatory at all temperatures. Conversely, a Japanese study found no effect of dex at 10 and $100 \mathrm{nM}$ on CBF using cultivated rat tracheal epithelial cells at $26.5^{\circ} \mathrm{C}$ (13). Given these conflicting results and lack of human studies, we investigated the effects of dex on cilia motility using human nasal epithelial cells.

Nasal epithelial cells are known to be satisfactory surrogates of tracheal and bronchial epithelial cells (14) and therefore bronchial muco-ciliary clearance (15). The CBF has proven to be strongly correlated with the efficacy of mucus transport, with a non-linear relationship noted such that even slight reductions in CBF can translate into significant impairment in muco-ciliary transport
(15). To interrogate the effects of the various drugs on CBF, we used concentrations equivalent to therapeutic doses and examined all samples at physiological temperature and at $15^{\circ} \mathrm{C}$, the latter to simulate hypothermia during $\mathrm{CPB}$ surgery. We added fen to replicate our mouse study. After exposing human respiratory epithelial cells to dex, fen, and dex + fen, we found a significant cilia-stimulatory effect at $37^{\circ} \mathrm{C}$, but a significant cilia-inhibitory effect at $15^{\circ} \mathrm{C}$ with all drugs. This suggests that administration of dex at physiologic temperatures would not cause cilia inhibition. This finding is important because this drug is mainly administered in critically ill patients who frequently have abolished airway reflexes, and are predisposed to pulmonary morbidity. Our finding of a cilia-inhibitory effect at low temperatures would suggest these drugs might have unfavorable effects in hypothermic patients, such as those undergoing CPB surgery. If cilia motility can be restored with re-warming the patient, such risks may be minimal. Further studies are needed to examine the reversibility of the low temperature effects.

We did not find significant correlation between drug concentration and CBF (e.g., higher concentrations did not cause a greater magnitude change in $\mathrm{CBF}$ ). Furthermore, no significant changes in $\mathrm{CBF}$ over time were observed at $15^{\circ} \mathrm{C}$ (e.g., no differences between 5 and $30 \mathrm{~min}$ ). This suggests that dex and fen does not produce progressively more depressive effects over time with drug exposure in hypothermia. In contrast, there was a significant time effect with drug exposure at $37^{\circ} \mathrm{C}$. Longer exposure with dex or dex + fen led to higher $\mathrm{CBF}$, whereas fen alone showed no difference. This suggests dex enhances CBF over time with drug exposure at $37^{\circ} \mathrm{C}$. However, as these agents are given over longer periods for sedation purposes both at 15 and $37^{\circ} \mathrm{C}$, the long-term effect on CBF remains unknown and requires further studies. There were significant drug interactions between dex and fen at $15^{\circ} \mathrm{C}$. This was indicated by our linear regression modeling, which showed non-additive effects, with less CBF inhibition observed then would be expected by summation of the individual drug effects. These findings suggest there may be overlap in the mechanisms of $\mathrm{CBF}$ regulation by drugs and temperature.

\section{POSSIBLE MECHANISM FOR EFFECTS OF DEX AND FEN ON CBF}

The cilia-inhibitory effects of dex and fen were significant at low temperatures, whereas we found a significant trend toward ciliastimulation at $37^{\circ} \mathrm{C}$ (except for dex $5 \mathrm{~nm}$ at $5 \mathrm{~min}$ ). Temperature augments $\mathrm{CBF}$ in a sigmoid fashion, from cilia stasis below $10^{\circ} \mathrm{C}$ to a near optimal rate at $32^{\circ} \mathrm{C}(16)$. Low temperatures have been shown to inhibit adenyl cyclase activity, reduce cAMP concentrations and alter PKC and CAMKII activity in ciliated cells $(17,18)$. Studies have shown alterations in adrenergic and opioid receptor affinity in response to different agonists during hypothermia (17). Hypothermia may favor receptor affinity and second messenger profile that potentiates the individual and combined effects of dex and fen, thus producing synergistic cilia inhibition between drugs and temperature. In contrast, higher temperatures may produce a receptor affinity/second messenger configuration that might have opposing effects on CBF (19).

While our rt-PCR analysis did not detect expression of alphaadrenergic receptors in reciliating human airway epithelia, we 
have observed low-level expression of alpha-2 adrenergic receptor transcripts in RNA-seq analysis of whole human respiratory epithelia obtained from nasal scrapes (M. Zahid and C. Lo, unpublished observations). This would suggest dex could act through the alpha-2 adrenergic receptor to modulate CBF in the human respiratory epithelia. The classical alpha-2 pathway is known to cause Gi-mediated adenyl cyclase inhibition, which would cause reductions in cAMP levels and intracellular calcium (20). However, as the transcript abundance was low, the effects of dex may involve another pathway. It is reported that dex blocks muscarinic subtype 3 receptor in Xenopus oocytes and inhibits intracellular calcium elevation (21), but these results have not been described in human cells. Several studies have shown fen is antagonistic to the muscarinic 3 receptor $(22-24)$. An alternative explanation is that these drugs could act through a different cell type not present in the reciliating respiratory epithelia used for our rtPCR analysis. These cells may modulate CBF in the intact human respiratory epithelia via transmission of ions and/or second messengers by gap junction mediated cell-cell communication (25, 26). This also could account for the previous report that dex and fen did not alter CBF in cultured reciliated respiratory epithelial cells (13).

\section{LIMITATIONS}

We note the ciliated respiratory epithelia used for our analysis were removed from autonomic neural signaling and vascular supply, both of which are known to regulate CBF in vivo and are affected by dex (16). To maximize potential clinical relevance, drug concentrations used in this study were equivalent to therapeutic doses and all samples were examined at physiologic temperature and conditions mimicking hypothermia during $\mathrm{CPB}$. Further studies are needed to evaluate the effect of dex in vivo. As clinical outcomes were not examined in this study, our results should be considered hypothesis generating and further studies are needed to see how these in vitro observations of the effects of dex on CBF translate into being clinically relevant.

\section{CONCLUSION}

Nasal epithelial cells are known to be satisfactory surrogates of tracheal and bronchial epithelial cells. In the present study, we found that dex and fen are cilia-inhibitory at $15^{\circ} \mathrm{C}$, and have ciliastimulatory effects on $\mathrm{CBF}$ at physiologic temperatures. Increasing dose and combining both agents with exposure up to $30 \mathrm{~min}$ did not produce additional changes in CBF. Combination of $\mathrm{dex}+\mathrm{fen}$ showed positive interaction, causing less cilia inhibition at $15^{\circ} \mathrm{C}$. In contrast, no interaction between dex and fen was observed at $37^{\circ} \mathrm{C}$. Whether these effects translate into clinical consequences during hypothermia, as with CBP surgery, or if this can be reversed upon temperature normalization, will require further studies. In addition, further studies are needed to delineate the receptors and second messengers regulating cilia motility in the human respiratory epithelia and the mechanism by which dex and fen modulates $\mathrm{CBF}$.

\section{SUPPLEMENTARY MATERIAL}

The Supplementary Material for this article can be found online at http://www.frontiersin.org/Journal/10.3389/fped.2015. 00007/abstract

\section{REFERENCES}

1. Venn RM, Hell J, Grouds RM. Respiratory effects of dexmedetomidine in the surgical patient requiring intensive care. Crit Care Med (2000) 4:302-8. doi: $10.1186 / \mathrm{cc} 712$

2. Martin E, Ramsay G, Mantz J, Sum-Ping ST. The role of the alpha2-adrenoceptor agonist dexmedetomidine in postsurgical sedation in the intensive care unit. J Intensive Care Med (2003) 18:29-41. doi:10.1177/0885066602239122

3. Chrysostomou C, Di Filippo S, Manrique AM, Schmitt CG, Orr RA, Casta A, et al. Use of dexmedetomidine in children after cardiac and thoracic surgery. Pediatr Crit Care Med (2006) 7:126-31. doi:10.1097/00130478-20060300000030

4. Clary Meinesz CF, Cosson J, Huitorel P, Blaive B. Temperature effect on ciliary beat frequency of human nasal and tracheal ciliated cells. Biol Cell (1992) 76(3):335-8. doi:10.1016/0248-4900(92)90436-5

5. Selwyn DA, Raphael JH, Lambert DG, Langton JA. Effects of morphine on human nasal cilia beat frequency in vitro. Br J Anaesth (1996) 76(2):274-7. doi:10.1093/bja/76.2.274

6. Ledowski T, Paech MJ, Patel B, Schug SA. Bronchial mucus transport velocity in patients receiving propofol and remifentanil versus sevoflurane and remifentanil anesthesia. Anesth Analg (2006) 102(5):1427-30. doi:10.1213/01. ane.0000204317.78586.07

7. Reves JG, Glass PS, Lubarsky DA, McEvoy MD. Intravenous nonopioid anesthetics. In: Miller RD, editor. Miller's Anesthesia. Philadelphia, PA: Elsevier Churchill Livingstone (2005). p. 317-78.

8. Fukuda K. Intravenous opioid anesthetics. In: Miller RD, editor. Miller's Anesthesia. Philadelphia, PA: Elsevier Churchill Livingstone (2005). p. 379-437.

9. Jorissen M, Van der Schueren B, Van den Berghe H, Cassiman JJ. The preservation and regeneration of cilia on human nasal epithelial cells cultured in vitro. Arch Otorhinolaryngol (1989) 246(5):308-14. doi:10.1007/ BF00463582

10. Chrysostomou C, Sanchez de Toledo J, Avolio T, Motoa MV, Berry D, Morell VO, et al. Dexmedetomidine use in a pediatric cardiac intensive care unit: can we use it in infants after cardiac surgery? Pediatr Crit Care Med (2009) 10(6):654-60. doi:10.1097/PCC.0b013e3181a00b7a

11. Barton KP, Munoz R, Morell VO, Chrysostomou C. Dexmedetomidine as the primary sedative during invasive procedures in infants and toddlers with congenital heart disease. Pediatr Crit Care Med (2008) 9(6):612-5. doi:10.1097/ PCC.0b013e31818d320d

12. Christopher AB, Ochoa S, Krushansky E, Francis R, Tian X, Zahid M, et al. The effects of temperature and anesthetic agents on ciliary function in murine respiratory epithelia. Front Pediatr (2014) 2:111. doi:10.3389/fped.2014. 00111

13. Iida H, Matsuura S, Shirakami G, Tanimoto K, Fukuda K. Differential effects of intravenous anesthetics on ciliary motility in cultured rat tracheal epithelial cells. Can J Anaesth (2006) 53(3):242-9. doi:10.1007/BF03022209

14. Low PP, Luk CK, Dulfano MT, Finch PJ. Ciliary beat frequency of human respiratory tract by different sampling techniques. Am Rev Respir Dis (1984) 130:497-8.

15. Duchateau GS, Graamans K, Zuidema J, Merkus FW. Correlation between nasal cilia beat frequency and mucus transport rate in volunteers. Laryngoscope (1985) 95:854-9. doi:10.1288/00005537-198507000-00022

16. Mwimbi XK, Muimo R, Green MW, Mehta A. Making human nasal cilia beat in the cold: a real time assay for cell signalling. Cell Signal (2003) 15(4):395-402. doi:10.1016/S0898-6568(02)00143-2

17. Schultz JE, Klumpp S. Adenyl cyclase in cilia from paramecium: localization and partial characterization. FEBS Lett (1983) 154:2. doi:10.1016/0014-5793(83) 80180-X

18. Haenisch B, Walstab J, Herberhold S, Bootz F, Tschaikin M, Ramseger R, et al. Alpha-adrenoceptor agonistic activity of oxymetazoline and xylometazoline. Fundam Clin Pharmacol (2010) 24(6):729-39. doi:10.1111/j.1472-8206.2009. 00805.x

19. Van den Broek MP, Groenendaal F, Egberts AC, Rademaker CM. Effects of hypothermia on pharmacokinetics and pharmacodynamics: a systematic review of preclinical and clinical studies. Clin Pharmacokinet (2010) 49(5):277-94. doi:10.2165/11319360-000000000-00000

20. Brunton L, Chabner B, Knollman B. Goodman \& Gilman's: The Pharmacological Basis of Therapeutics. 11th ed. New York, NY: McGraw-Hill (2005).

21. Takizuka A, Minami K, Uezono Y, Horishita T, Yokoyama T, Shiraishi M, et al. Dexmedetomidine inhibits muscarinic type 3 receptors expressed in 
Xenopus oocytes and muscarine-induced intracellular Ca2+ elevation in cultured rat dorsal root ganglia cells. Naunyn Schmiedebergs Arch Pharmacol (2007) 375(5):293-301. doi:10.1007/s00210-007-0168-4

22. Yamanoue T, Brum JM, Estafanous FG, Khairallah PA, Ferrario CM. Fentanyl attenuates porcine coronary arterial contraction through M3-muscarinic antagonism. Anesth Analg. (1993) 76(2):382-90.

23. Sohn JT, Ok SH, Kim HJ, Moon SH, Shin IW, Lee HK, et al. Inhibitory effect of fentanyl on acetylcholine-induced relaxation in rat aorta. Anesthesiology (2004) 101(1):89-96. doi:10.1097/00000542-200407000-00015

24. Hustveit O. Binding of fentanyl and pethidine to muscarinic receptors in rat brain. Jpn J Pharmacol (1994) 64(1):57-9. doi:10.1254/jjp.64.57

25. Francis RJ, Chatterjee B, Loges NT, Zentgraf H, Omran H, Lo CW. Initiation and maturation of cilia-generated flow in newborn and postnatal mouse airway. Am J Physiol Lung Cell Mol Physiol (2009) 296(6):L1067-75. doi:10.1152/ajplung.00001.2009

26. Sanderson MJ, Chow I, Dirksen ER. Intercellular communication between ciliated cells in culture. Am J Physiol Cell Physiol (1998) 254:C63-74.
Conflict of Interest Statement: The authors declare that the research was conducted in the absence of any commercial or financial relationships that could be construed as a potential conflict of interest.

Received: 04 November 2014; accepted: 26 January 2015; published online: 11 February 2015.

Citation: Welchering N, Ochoa S, Tian X, Francis R, Zahid M, Muñoz R and Lo $C W$ (2015) Dexmedetomidine and fentanyl exhibit temperature dependent effects on human respiratory cilia. Front. Pediatr. 3:7. doi: 10.3389/fped.2015.00007

This article was submitted to Pediatric Critical Care, a section of the journal Frontiers in Pediatrics.

Copyright (c) 2015 Welchering, Ochoa, Tian, Francis, Zahid, Muñoz and Lo. This is an open-access article distributed under the terms of the Creative Commons Attribution License (CC BY). The use, distribution or reproduction in other forums is permitted, provided the original author(s) or licensor are credited and that the original publication in this journal is cited, in accordance with accepted academic practice. No use, distribution or reproduction is permitted which does not comply with these terms. 